\title{
Data report: the Late Quaternary fossil record of holoplanktonic gastropods at IODP Sites U1395 and U1394'
}

\author{
Deborah Wall-Palmer, ${ }^{2}$ Christopher W. Smart, ${ }^{2}$ and Malcolm B. Hart ${ }^{2}$
}

\begin{abstract}
Chapter contents

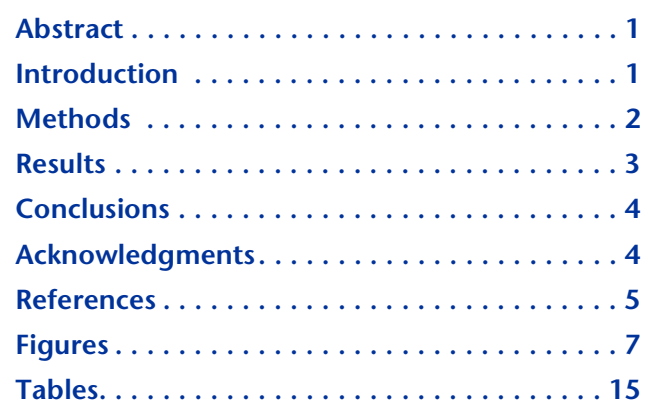

'Wall-Palmer, D., Smart, C.W., and Hart, M.B., 2015. Data report: the Late Quaternary fossil record of holoplanktonic gastropods at IODP Sites U1395 and U1394. In Le Friant, A., Ishizuka, O., Stroncik, N.A., and the Expedition 340 Scientists, Proceedings of the Integrated Ocean Drilling Program, 340: Tokyo (Integrated Ocean Drilling Program Management International, Inc.). doi:10.2204/iodp.proc.340.203.2015

${ }^{2}$ School of Geography, Earth and Environmental Sciences, Plymouth University, Plymouth, PL4 8AA, UK. Correspondence author:

deborah.wall-palmer@plymouth.ac.uk

\begin{abstract}
Living holoplanktonic gastropods (pteropods and heteropods) are a common component of the zooplankton at all latitudes and are highly sensitive indicators of surface ocean changes. Despite having a fossil record that may extend from the Jurassic, there are few detailed stratigraphic sequences of holoplanktonic gastropods and, consequently, they are rarely used in biostratigraphy. This is largely due to the susceptibility of their delicate aragonitic shells to dissolution. However, in well-preserved sediments, fossil holoplanktonic gastropods have the potential to contribute valuable information for paleoceanography, paleoecology, and stratigraphic correlation.

Here we present a $\sim 300$ ky record of holoplanktonic gastropods from two sites cored/drilled offshore of Montserrat during Integrated Ocean Drilling Program (IODP) Expedition 340. Oxygen isotope stratigraphy was used to produce a stratigraphic framework for each site, which was compared and correlated to the corresponding downcore abundances of holoplanktonic gastropods. In addition, the record of previously cored Site CAR-MON 2, 15 $\mathrm{km}$ southwest of IODP Site U1396, was compared to data at Sites U1395 and U1394 to identify species associations that are reproducible across the area. A number of downhole distributions were found to correlate significantly across the three sites, highlighting ten key species, three of which (Heliconoides inflatus, Creseis clava, and Atlanta plana) display significant relationships to multiple holoplanktonic gastropod species. Fluctuations in species abundance were found not to be related to changes in temperature, locally or globally, and were more likely to indicate predator-prey relationships or competition for prey. This made holoplanktonic gastropod assemblages unsuitable as stratigraphic markers in this area but improves our understanding of holoplanktonic gastropod ecology in the Caribbean Sea.
\end{abstract}

\section{Introduction}

Holoplanktonic gastropods are uniquely adapted to live their entire lives within the plankton. They can reach densities of up to $10,000 / \mathrm{m}^{3}$, constituting an important component of the ocean food web at all latitudes (Fabry et al., 2008). There are two groups of holoplanktonic gastropods: pteropods (Thecosomata and Gymnosomata) and heteropods (Pterotracheoidea). Within these 
groups there are shelled, partially shelled, and shellless species, although shell-less species still have a shell at the larval stage. Both pteropod and heteropod shells are small, delicate, and formed of aragonite and are, consequently, particularly susceptible to dissolution (Fabry, 1990) and mechanical damage. Their shells are, however, frequently preserved in shallow warm-water regions that are supersaturated with respect to aragonite. Offshore of Montserrat, in an area of exceptional calcium carbonate preservation, the fossil record of holoplanktonic gastropod shells within the sediments is rich and accurately reflects the living population at the time of deposition (Wall-Palmer et al., 2014b). Moreover, any sediment transport, such as density current deposits that are common in this area (Watt et al., 2012; Trofimovs et al., 2013; Cassidy et al., 2014), fragments the delicate shells, meaning that, where shells are present, their stratigraphy is unlikely to have been affected by reworking. All species of holoplanktonic gastropods presented here are extant, and living examples can be found in the oceans today.

Holoplanktonic gastropods are sensitive to environmental changes (Maas et al., 2012), so their fossil record can be used as an archive of past ocean surface conditions (Wall-Palmer et al., 2013, 2014b). Changes in dominant holoplanktonic gastropod species are often temperature driven, especially where temperature has a large range over time (e.g., during the Late Pleistocene in the Mediterranean Sea [Sbaffi et al., 2001; Wall-Palmer et al., 2014b]). In the Lesser Antilles, however, where temperature variations are smaller over time, changes in species abundance can be more difficult to interpret. Furthermore, there are a number of holoplanktonic gastropods, in particular the heteropods, for which we know very little about their environmental preferences, despite being extant. This makes it difficult to use holoplanktonic gastropods as stratigraphic marker species in such areas and obstructs their potential as paleoceanographic indicators.

In this study, we present the downcore distribution of all holoplanktonic gastropod shells found at Integrated Ocean Drilling Program (IODP) Sites U1395 and U1394. Although their analysis has not allowed detailed interpretations of the paleoceanography of this area, a number of species associations have been identified. It is anticipated that these data will help to stimulate more widespread study of holoplanktonic gastropods in marine sediment cores, as well as contributing new ecological information that can be applied to living populations, in particular the heteropods, whose environmental requirements are currently poorly known.

\section{Methods}

IODP Expedition 340 successfully collected cores from three sites (U1396, U1395, and U1394) offshore of Montserrat in the Lesser Antilles, Caribbean Sea (Fig. F1). Sites U1395 and U1394 lie within the Bouillante-Montserrat Graben, $\sim 15$ and $\sim 33 \mathrm{~km}$ from the island, respectively, and in the path of major submarine landslides (Trofimovs et al., 2013). Sedimentation at these two sites has been considerably affected by the input of volcanic material and resedimentation by density current deposits (Expedition 340 Scientists, 2013). Here, we present a $300 \mathrm{ky}$ holoplanktonic gastropod record from Sites U1395 and U1394 that corresponds to 166 and $\sim 44$ m hole depth, respectively. Material analyzed was collected from undisturbed hemipelagic sediments only and the data are presented with gaps where disturbed material interrupts the record.

The holoplanktonic gastropod content of Site U1396 is not presented here because the site does not preserve a record of holoplanktonic gastropods between $\sim 43$ and $250 \mathrm{ky}$ (Wall-Palmer et al., 2014a), despite being positioned out of the main path of density current deposits. This absence was attributed to winnowing by bottom water currents that are thought to have removed the delicate shells. Previously cored Site CAR-MON 2 (Fig. F1) records a rich fossil record of holoplanktonic gastropods (Le Friant et al., 2008; Wall-Palmer et al., 2013, 2014b), despite being only $\sim 15 \mathrm{~km}$ southwest of Site U1396. Therefore, Site CAR-MON 2 was used as a comparison site, rather than Site U1396. All drilling and coring sites are above the aragonite lysocline, reducing any effects of postdepositional dissolution upon the aragonitic gastropod shells.

\section{Core sampling}

Holes U1394A, U1394B, and U1395B were sampled at $\sim 50 \mathrm{~cm}$ intervals $(10,2$, and $6 \mathrm{ky}$, respectively) from 0 to $5.9,91.8$ to 166.1 , and 0 to 43.6 meters below seafloor (mbsf), respectively. All sampling was carried out at the Gulf Coast Core Repository in College Station, Texas (USA). Samples were taken from hemipelagic sediment only to avoid the effects of reworking and volcanic input, which can dissolve holoplanktonic gastropod shells (Wall-Palmer et al., 2011). Sample processing was carried out at Plymouth University in the United Kingdom. Samples were dried in an oven at $40^{\circ} \mathrm{C}$ for $24 \mathrm{~h}$ to facilitate the subsequent removal of clay particles. Samples were then rehydrated and washed over a $63 \mu \mathrm{m}$ sieve. Both the $<63$ and $>63 \mu \mathrm{m}$ fractions were collected, filtered, and dried in an oven at $40^{\circ} \mathrm{C}$ for $24 \mathrm{~h}$. 


\section{Microfossil analysis}

For each sample, just more than 300 (or until the sample was exhausted) holoplanktonic gastropod specimens were counted and identified from the $>150 \mu \mathrm{m}$ size fraction. Only whole specimens were counted to avoid the distortion produced by several fragments of the same specimen. Pteropod species identification was made using the keys published by Bé and Gilmer (1977) and Janssen (2012). Heteropod species identification was made using Seapy (1990), Seapy et al. (2003), the Tree of Life web project (tolweb.org/Atlantidae), and Janssen (2012). Counts of holoplanktonic gastropods are expressed as a percentage (relative abundance) of the total number of specimens per sample.

A large number of the heteropod specimens were juveniles, which complicates their species identification. Therefore, the species Atlanta peronii, Atlanta gaudichaudi, Atlanta rosea, Atlanta lesueurii, and Atlanta oligogyra are presented here as the $A$. peronii group because their juvenile shells could not be differentiated.

\section{Results}

A total of 29 holoplanktonic gastropod species within 16 genera and unidentified gymnosome veliger shells (Fig. F2) were identified in sediments offshore of Montserrat (Figs. F3, F4, F5, F6, F7, F8). Of the identified species, 16 are thecosome (shelled) pteropods, 1 is a gymnosome (shell-less) pteropod, and 12 are heteropods: 1 in the family Pterotracheidae (shell-less), 2 in the family Carinariidae (partially shelled), and 9 in the family Atlantidae (shelled). Well-preserved holoplanktonic gastropods were found in all samples analyzed, except at 122.322123.323 and 130.490-131.545 mbsf in Hole U1394B. The high volume of volcanic material in these samples suggests that they represent resedimented material and, thus, holoplanktonic remains within them were fragmented beyond identification.

No species datums (first occurrences or last occurrences) were identified during the geological period studied. Therefore, all (extant) holoplanktonic gastropod species encountered during this study have a fossil record of at least $300 \mathrm{ky}$.

\section{Dominant species and their environmental requirements}

At all sites analyzed, there is a single dominant species, Heliconoides inflatus, that constitutes between $3 \%$ and $65 \%$ (average $=28 \%$ ) in Holes U1394A and $\mathrm{U} 1394 \mathrm{~B}, 13 \%$ and $75 \%$ (average $=48 \%$ ) in Hole $\mathrm{U} 1395 \mathrm{~B}$, and $10 \%$ and $68 \%$ (average $=40 \%$ ) at Site
CAR-MON 2 (Figs. F3, F4, F5). H. inflatus is a warmwater cosmopolitan species (Bé and Gilmer, 1977) that tolerates a wide range of water temperatures $\left(14^{\circ} \mathrm{C}-28^{\circ} \mathrm{C}\right)$ (Table T1). This species is found in all samples analyzed, indicating that the water offshore of Montserrat was $14^{\circ} \mathrm{C}-28^{\circ} \mathrm{C}$ at all times during the last $300 \mathrm{ky}$.

Five further species (Atlanta selvagensis, Gleba cordata, Limacina bulimoides, Limacina trochiformis and Styliola subula) were found to be abundant across all sites. There are also a number of species that are abundant at only one or two of the sites. This variation in species abundance across a relatively small area of ocean is probably caused by the patchy, swarming nature of holoplanktonic gastropods (Lalli and Gilmer, 1989; Mathew et al., 1990). These species (Table T1) all indicate subtropical to tropical warm waters (Bé and Gilmer, 1977), which supports published data for the water temperatures of this region over the last $300 \mathrm{ky}$ (Schmidt et al., 2006; Foster, 2008).

\section{Species changes with global temperature}

The ratio of oxygen isotopes ${ }^{16} \mathrm{O}$ and ${ }^{18} \mathrm{O}$ measured from the calcium carbonate of foraminifers are used as a proxy for the global ice volume and general trends in global temperature. In ocean waters, a high proportion of lighter ${ }^{16} \mathrm{O}$, which preferentially evaporates from ocean waters, indicates that ${ }^{16} \mathrm{O}$ is being returned to the ocean through precipitation. However, a lower proportion of ${ }^{16} \mathrm{O}$ indicates that following evaporation ${ }^{16} \mathrm{O}$ is locked up in ice and not returned to the ocean, indicating a global cooling. This chemical signature becomes incorporated into the shells of marine organisms and is measured using geochemical techniques (Coussens et al., 2015).

The abundance of all holoplanktonic gastropod species was correlated (using a Pearsons correlation in the PAST statistics package) to the corresponding oxygen isotope data throughout the study interval of each site (Tables T2, T3, T4) to identify any trends in species composition with global temperature changes. A total of 11 species were found to show a significant correlation to the oxygen isotope record at Site U1394, 6 at Site U1395, and 13 at Site CARMON 2. However, only one of the correlations ( $A$. peronii group) was reproducible across all three sites. Therefore, although holoplanktonic gastropod species are clearly influenced by global temperature changes, they are not closely associated with small changes in water temperature, and the correlations at singular sites are likely to be coincidental.

The abundance of the warm-water planktonic foraminifer Globorotalia menardii was used as a local indi- 
cator of temperature (Le Friant et al., 2008; Coussens et al., 2015). A total of 5 species were found to show a significant correlation to the abundance of G. menardii at Site U1394, 9 at Site U1395, and 15 at Site CAR-MON 2 (Tables T2, T3, T4). However, none of the correlations were reproducible across all three sites. This supports the finding that changes in species abundances are influenced by temperature but not driven by it. This is likely to be because many of the holoplanktonic gastropod species have a wide temperature tolerance relative to the small changes in Caribbean Sea temperature (Bé and Gilmer, 1977) and are thus not greatly influenced by these changes.

\section{Species associations}

The abundances of holoplanktonic gastropod species were correlated against each other to highlight species associations (Tables T2, T3, T4). Eight species associations were reproducible across all three sites. Four associations show a positive correlation and four show a negative correlation. Positive correlations suggest that the two associated species have the same environmental requirements and can improve our understanding of some poorly understood species. For example, we do not know the environmental preferences of the atlantid heteropod species $\mathrm{Fi}$ roloida desmarestia. However, it shows a reproducible positive correlation to the relatively well studied pteropod species Creseis chierchiae, suggesting that they are influenced by similar conditions.

Five of the eight species associations are between a heteropod species and a pteropod species. This may indicate predator-prey relationships because heteropods are carnivorous and are known to prey upon species of pteropod (Richter, 1982; Newman, 1990). However, in four of the five associations, the correlation is negative, indicating that when the pteropod species is abundant the heteropod species is rare. This is the opposite trend that would be expected from a predator-prey relationship, where abundant pteropods would be accompanied by abundant heteropods. This relationship, therefore, suggests that heteropods are feeding on something that is in competition with the pteropods for food but does not leave fossil remains (e.g., copepods). When the abundance of this prey is high, the number of heteropods increases; however, competition for pteropod food is also high, so pteropods numbers are low. When the abundance of the alternative prey is low, heteropod numbers are also low, but the food available to pteropods is increased, so pteropod numbers also increase. This reveals that pteropods are not the favored prey for some species of heteropod.
Only a single, positive species association was found between two species of heteropod (A. plana and $A$. selvagensis). This supports recent research, which found that species of atlantid often exhibited species specific seasonal increases in abundance to avoid prey competition (Lemus-Santana et al., 2014). Although seasonal trends are unlikely to be detected in this relatively low resolution data, this behavior may partially explain why heteropod species are not generally found to be abundant at the same time.

The data suggest there are two particularly important species and one key species that show reproducible correlations to multiple other species. Creseis clava and $H$. inflatus correlate to two species and A. plana correlates to four species (including C. clava). The data do not indicate how these species are important to the ecosystem offshore of Montserrat, as they are all present at different abundances.

\section{Conclusions}

The variations in abundance and assemblage of holoplanktonic gastropods offshore of Montserrat are not closely related to changes in water temperature. This is because the species present have a wider temperature tolerance than the small changes in Caribbean Sea temperature over the last $300 \mathrm{ky}$. It is assumed that other factors, such as food sources have driven these changes. Therefore, the abundances of holoplanktonic gastropods are not suitable stratigraphic markers in this area.

Significant correlations between some species were reproducible across all sites and may be useful in helping us to understand the environmental requirements of poorly known species, in particular, the heteropods. Negative correlations between pteropod and heteropod species suggest that the preferential prey of heteropods was in competition with pteropods for resources. This also indicates that the preferred prey of heteropods are shell-less organisms such as copepods because they left no fossil trace. Three species were found to be associated with more than one other species, suggesting that they could have a key role in holoplanktonic gastropod ecology. However, the ecological and paleoceanographic significance of these species relationships could not be interpreted.

\section{Acknowledgments}

This research used samples and data provided by the Integrated Ocean Drilling Program (IODP). We would like to thank the crew and scientists who sailed on the R/V JOIDES Resolution during Expedi- 
tion 340. We would also like to thank Arie Janssen for reviewing this manuscript and for providing constructive comments and suggestions. Scanning electron microscopy was carried out at the Plymouth Electron Microscopy Centre (UK). This research was funded by a NERC research grant (NE/K002724/1) and a Leverhulme Trust research grant (RPG-2013363, 2014-2017).

\section{References}

Bé, A.W.H., and Gilmer, R.W., 1977. A zoogeographic and taxonomic review of Euthecosomatous pteropoda. In Ramsay, A.T.S. (Ed.), Oceanic Micropaleontology (Vol. 1): New York (Academic Press), 733-808.

Cassidy, M., Trofimovs, J., Watt, S.F.L., Palmer, M.R., Taylor, R.N., Gernon, T.M., Talling, P.J., and Le Friant, A., 2014. Multi-stage collapse events in the South Soufrière Hills, Montserrat as recorded in marine sediment cores. In Wadge, G., Robertson, R.E.A., and Voight, B. (Eds.), The Eruption of Soufriere Hills Volcano, Montserrat, from 2000 to 2010. Geological Society Memoirs, 39:383-397. http://dx.doi.org/10.1144/M39.20

Coussens, M.F., Wall-Palmer, D., Talling, P.J., Watt, S.F.L, Hatter, S.J., Cassidy, M., Clare, M., Jutzeler, M., Hatfield, R., McCanta, M., Kataoka, K.S., Endo, D., Palmer, M.R., Stinton, A., Fujinawa, A., Boudon, G., Le Friant, A., Ishizuka, O., Gernon, T., Adachi, T., Aljahdali, M., Breitkreuz, C., Fraas, A.J., Hornbach, M.J., Lebas, E., Lafuerza, S., Maeno, F., Manga, M., Martinez-Colon, M., McManus, J., Morgan, S., Saito, T., Slagle, A., Subramanyam, K.S.V., Tamura, Y., Trofimovs, J., Villemant, B., Wang, F., and the Expedition 340 Scientists, 2015. Synthesis: stratigraphy and age control for IODP Sites U1394, U1395, and U1396 offshore Montserrat in the Lesser Antilles. In Le Friant, A., Ishizuka, O., Stroncik, N.A., and the Expedition 340 Scientists, Proceedings of the Integrated Ocean Drilling Program, 340: Tokyo (Integrated Ocean Drilling Program Management International, Inc.).

Expedition 340 Scientists, 2013. Lesser Antilles volcanism and landslides: implications for hazard assessment and long-term magmatic evolution of the arc. IODP Preliminary Report, 340. http://dx.doi.org/10.2204/ iodp.pr.340.2012

Fabry, V.J., 1990. Shell growth rates of pteropod and heteropod molluscs and aragonite production in the open ocean: implications for the marine carbonate system. Journal of Marine Research, 48(1):209-222. http:// dx.doi.org/10.1357/002224090784984614

Fabry, V.J., Seibel, B.A., Feely, R.A., and Orr, J.C., 2008. Impacts of ocean acidification on fauna and ecosystem processes. ICES Journal of Marine Science, 65(3):414-432. http://dx.doi.org/10.1093/icesjms/fsn048

Foster, G.L., 2008. Seawater $\mathrm{pH}, \mathrm{pCO}_{2}$ and $\left[\mathrm{CO}^{2-}{ }_{3}\right]$ variations in the Caribbean Sea over the last 130 kyr: a boron isotope and B/Ca study of planktic foraminifera. Earth and Planetary Science Letters, 271(1-4):254-266. http:// dx.doi.org/10.1016/j.epsl.2008.04.015
Janssen, A.W., 2012. Late Quaternary to Recent holoplanktonic Mollusca (Gastropoda) from bottom samples of the eastern Mediterranean Sea: systematics, morphology. Bollettino Malacologico, 48(Suppl. 9):1-105.

Lalli, C.M., and Gilmer, R.W., 1989. Pelagic Snails: The Biology of Holoplanktonic Mollusks: Stanford, California (Stanford University Press).

Le Friant, A., Lock, E.J., Hart, M.B., Boudon, G., Sparks, R.S.J., Leng, M.J., Smart, C.W., Komorowski, J.C., Deplus, C., and Fisher, J.K., 2008. Late Pleistocene tephrochronology of marine sediments adjacent to Montserrat, Lesser Antilles volcanic arc. Journal of the Geological Society (London, U. K.), 165(1):279-289. http:// dx.doi.org/10.1144/0016-76492007-019

Lemus-Santana, E., Sanvicente-Añorve, L., Hermoso-Salazar, M., and Flores-Coto, C., 2014. The holoplanktonic Mollusca from the southern Gulf of Mexico. Part 1: Heteropods. Cahiers de Biologie Marine, 55:229-239.

Maas, A.E., Wishner, K.F., and Seibel, B.A., 2012. Metabolic suppression in thecosomatous pteropods as an effect of low temperature and hypoxia in the eastern tropical North Pacific. Marine Biology, 159(9):1955-1967. http:// dx.doi.org/10.1007/s00227-012-1982-x

Mathew, K.J., Naomi, T.S., Antony, G., and Solomon, K., 1990. Distribution and abundance of pteropod and heteropod molluscs in the EEZ and adjoining waters of India. Proceedings of the First Workshop on Scientific Results of FORV Sagar Sampada, 155-163.

Newman, L.J., 1990. The taxonomy, distribution and biology of Atlanta gaudichaudi Souleyet, 1952 (Gastropoda, Heteropoda) from the Great Barrier Reef, Australia. American Malacological Bulletin, 8:85-94.

Richter, G., 1982. Mageninhaltsuntersuchungen an Oxygyrus keraudreni (Lesueur) (Atlantidae, Heteropoda). Beispiel einer Nahrungskette im tropischen Pelagial. Senckenbergiana maritima, 14:47-77.

Sbaffi, L., Wezel, F.C., Kallel, N., Paterne, M., Cacho, I., Ziveri, P., and Shackleton, N., 2001. Response of the pelagic environment to palaeoclimatic changes in the central Mediterranean Sea during the Late Quaternary. Marine Geology, 178(1-4):39-62. http://dx.doi.org/10.1016/ S0025-3227(01)00185-2

Schmidt, M.W., Vautravers, M.J., and Spero, H.J., 2006. Western Caribbean sea surface temperatures during the late Quaternary. Geochemistry, Geophysics, Geosystems, 7(2):Q02P10. http://dx.doi.org/10.1029/ 2005GC000957

Seapy, R.R., 1990. The pelagic family Atlantidae (Gastropoda: Heteropoda) from Hawaiian waters: a faunistic survey. Malacologia, 32(1):107-130.

Seapy, R.R., Lalli, C.M., and Wells, F.E., 2003. Heteropoda from Western Australian waters. In Wells, F.E., Walker, D.I., and Jones, D.S. (Eds.), The Marine Flora and Fauna of Dampier, Western Australia: Perth, Western Australia (Western Australian Museum), 513-546.

Trofimovs, J., Talling, P.J., Fisher, J.K., Sparks, R.S.J., Watt, S.F.L., Hart, M.B., Smart, C.W., Le Friant, A., Cassidy, M., Moreton, S.G., and Leng, M.J., 2013. Timing, origin and emplacement dynamics of mass flows offshore of SE Montserrat in the last $110 \mathrm{ka}$ : implications for landslide 
and tsunami hazards, eruption history, and volcanic island evolution. Geochemistry, Geophysics, Geosystems, 14(2):385-406. http://dx.doi.org/10.1002/ggge.20052

Wall-Palmer, D., Coussens, M., Talling, P.J., Jutzeler, M., Cassidy, M., Marchant, I., Palmer, M.R., Watt, S.F.L., Smart, C.W., Fisher, J.K., Hart, M.B., Fraass, A., Trofimovs, J., Le Friant, A., Ishizuka, O., Adachi, T., Aljahdali, M., Boudon, G., Breitkreuz, C., Endo, D., Fujinawa, A., Hatfield, R., Hornbach, M.J., Kataoka, K., Lafuerza, S., Maeno, F., Manga, M., Martinez-Colon, M., McCanta, M., Morgan, S., Saito, T., Slagle, A.L., Stinton, A.J., Subramanyam, K.S.V., Tamura, Y., Villemant, B., and Wang, F., 2014a. Late Pleistocene stratigraphy of IODP Site U1396 and compiled chronology offshore of south and south west Montserrat, Lesser Antilles. Geochemistry, Geophysics, Geosystems, 15(7):3000-3020. http://dx.doi.org/10.1002/2014GC005402

Wall-Palmer, D., Jones, M.T., Hart, M.B., Fisher, J.K., Smart, C.W., Hembury, D.J., Palmer, M.R., and Fones, G.R., 2011. Explosive volcanism as a cause for mass mortality of pteropods. Marine Geology, 282(3-4):231-239. http:// dx.doi.org/10.1016/j.margeo.2011.03.001

Wall-Palmer, D., Smart, C.W., and Hart, M.B., 2013. In-life pteropod dissolution as an indicator of past ocean car- bonate saturation. Quaternary Science Reviews, 81:29-34. http://dx.doi.org/10.1016/j.quascirev.2013.09.019

Wall-Palmer, D., Smart, C.W., Hart, M.B., Leng, M.J., Borghini, M., Manini, E., Aliani, S., and Conversi, A., 2014b. Late Pleistocene pteropods, heteropods and planktonic foraminifera from the Caribbean Sea, Mediterranean Sea and Indian Ocean. Micropaleontology, 60(6):557-578.

Watt, S.F.L., Talling, P.J., Vardy, M.E., Masson, D.G., Henstock, T.J., Hühnerbach, V., Minshull, T.A., Urlaub, M., Lebas, E., Le Friant, A., Berndt, C., Crutchley, G.J., and Karstens, J., 2012. Widespread and progressive seafloorsediment failure following volcanic debris avalanche emplacement: landslide dynamics and timing offshore Montserrat, Lesser Antilles. Marine Geology, 323-325:6994. http://dx.doi.org/10.1016/j.margeo.2012.08.002

Initial receipt: 26 February 2015

Acceptance: 16 August 2015

Publication: 11 December 2015

MS 340-203 
Figure F1. Site CAR-MON 2 location map with respect to IODP Expedition 340 sites offshore of Montserrat. SSH $=$ South Soufrière Hills Volcano.

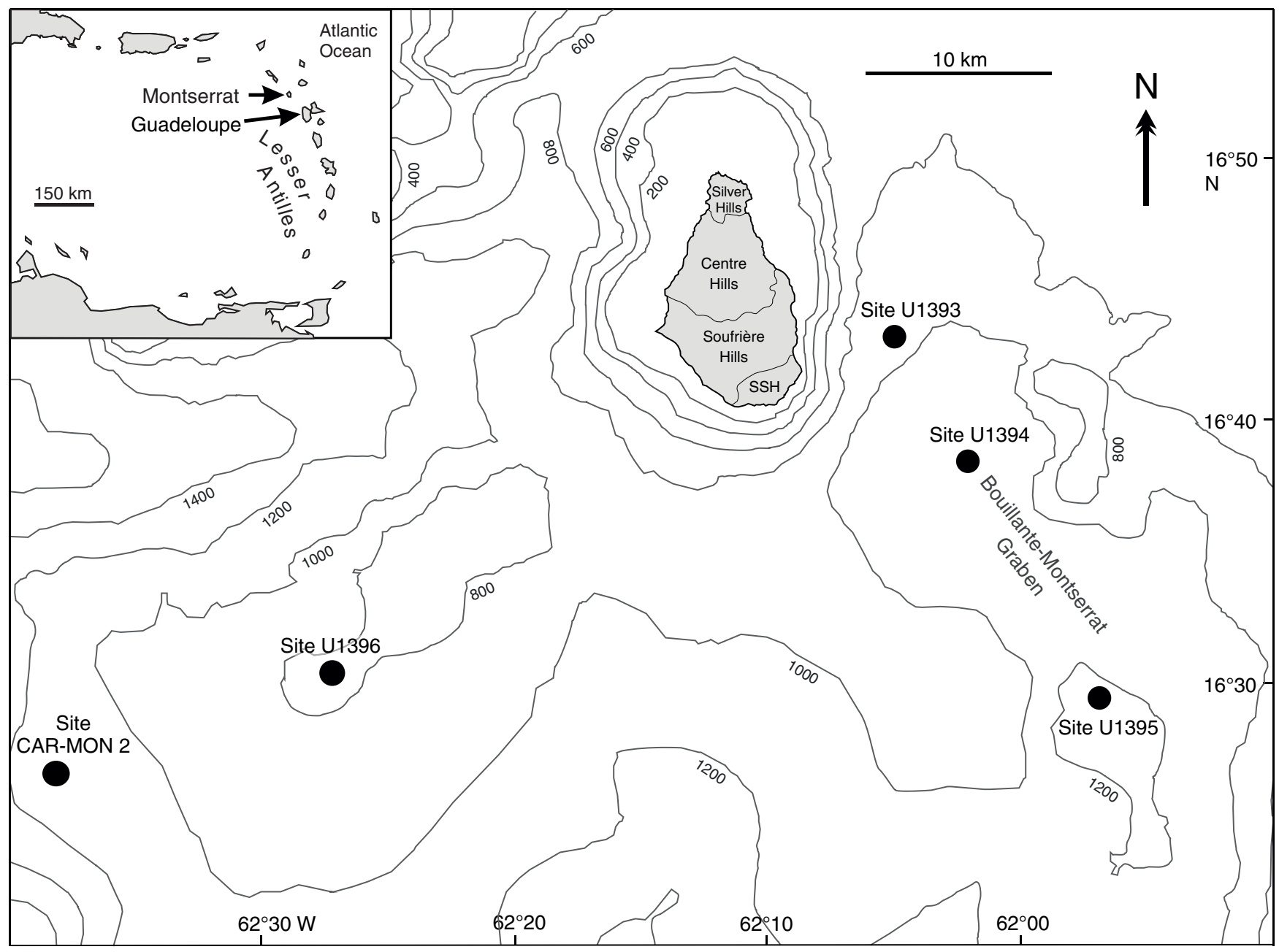


Figure F2. Scanning electron microscopy images of larval shells, Hole U1395B. (1-3) Unidentified gymnosome veligers, (4) Firoloida desmarestia, (5) Gleba cordata, (6) unidentified benthic gastropod larval shell, (7) Carinaria pseudorugosa. Scale bars $=50 \mu \mathrm{m}$.

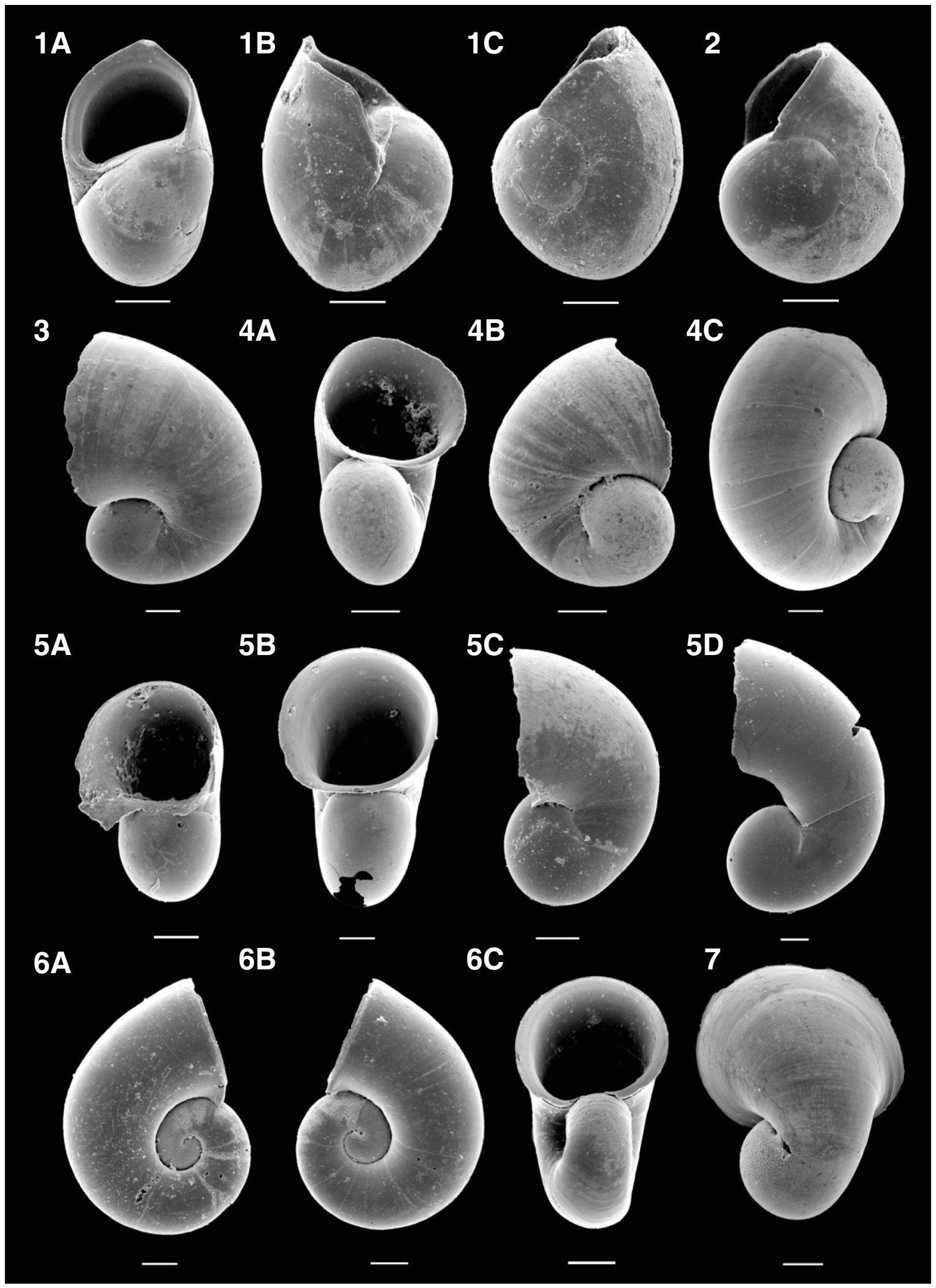


Figure F3. Dominant species (generally abundance $>10 \%$ ) of holoplanktonic gastropods in the upper $167 \mathrm{~m}$ at Site U1394 with oxygen isotope stratigraphy (Coussens et al., 2015). MIS = marine isotope stage.

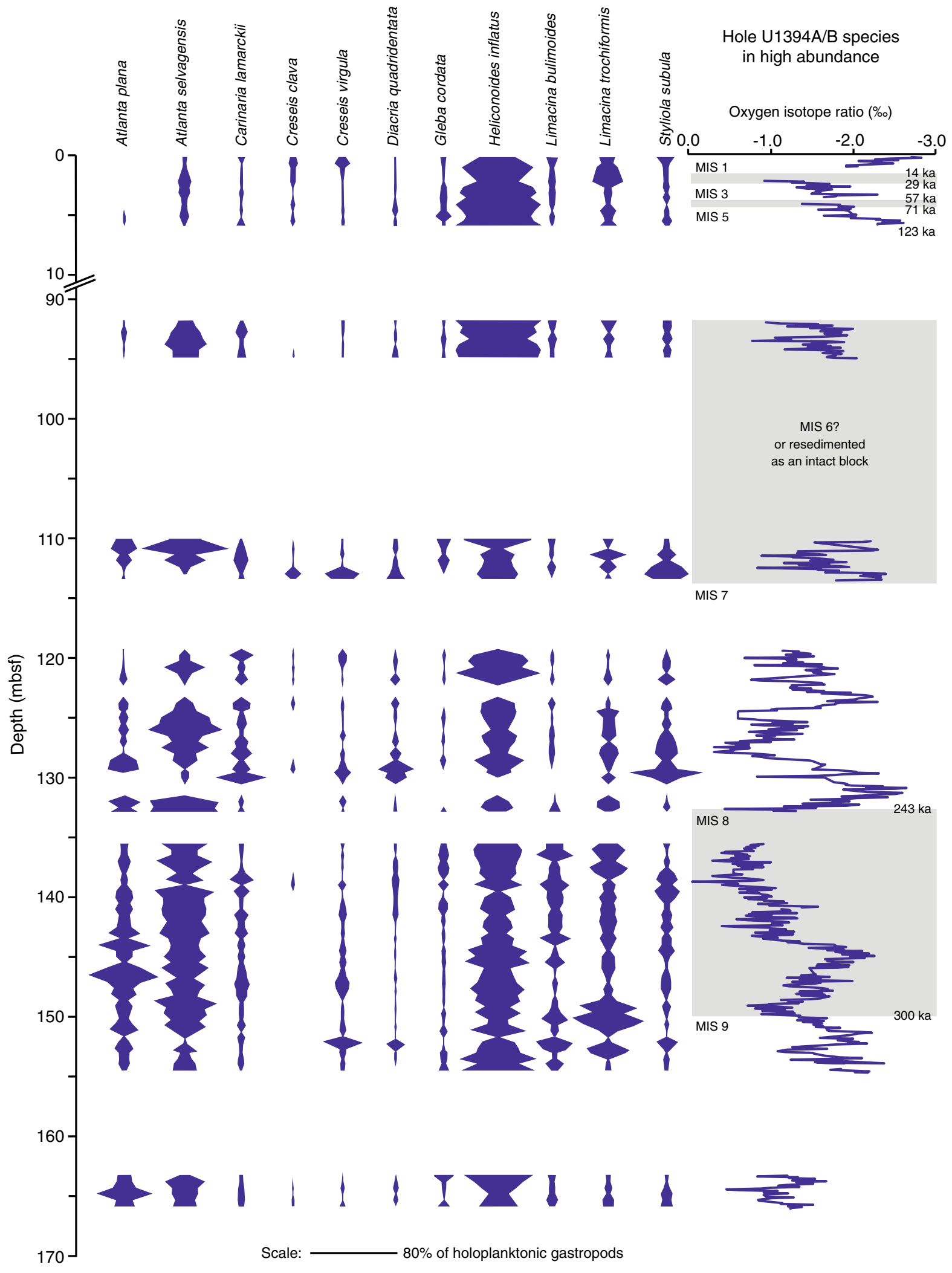


Figure F4. Dominant species (generally abundance $>10 \%$ ) of holoplanktonic gastropods in the upper $30 \mathrm{~m}$ at Site U1395 with oxygen isotope stratigraphy (Coussens et al., 2015). MIS = marine isotope stage.

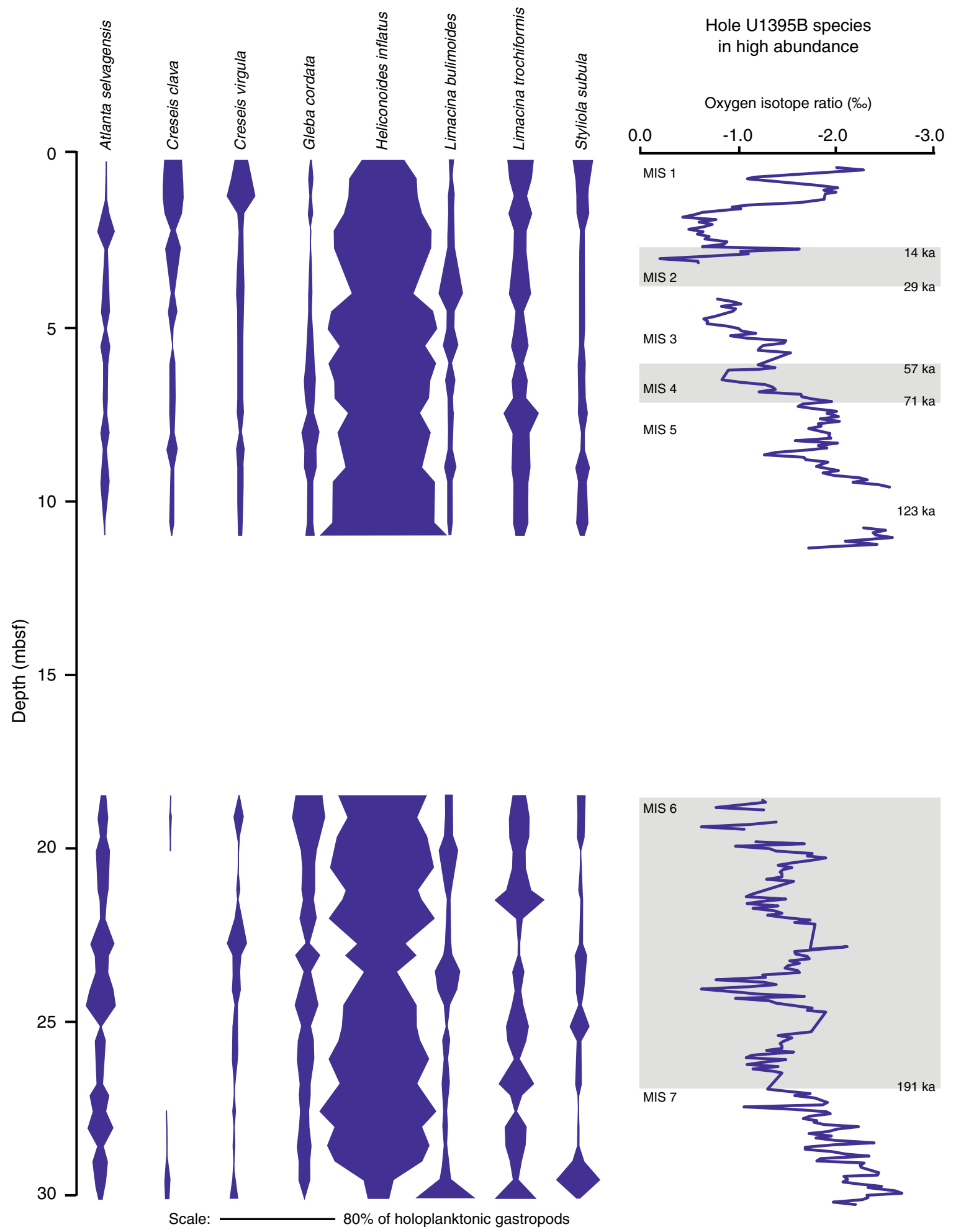


Figure F5. Dominant species (generally abundance $>10 \%$ ) of holoplanktonic gastropods in the upper $6 \mathrm{~m}$ at Site CAR-MON 2 (Wall-Palmer et al., 2014b) with oxygen isotope stratigraphy (Le Friant et al., 2008). MIS = marine isotope stage.

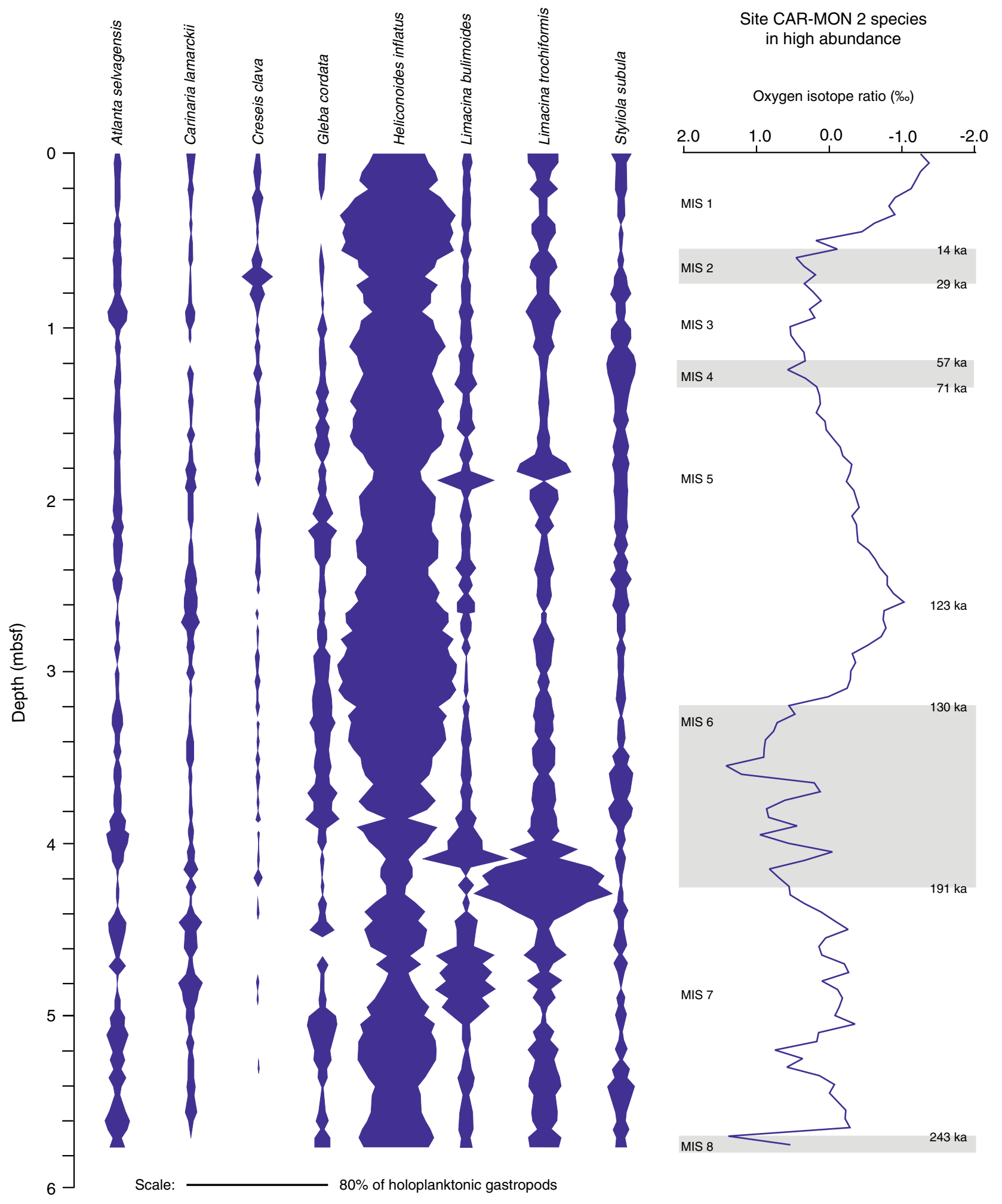


Figure F6. Common to rare species (generally abundance $<10 \%$ ) of holoplanktonic gastropods in the upper $167 \mathrm{~m}$ at Site U1394 with oxygen isotope stratigraphy (Coussens et al., 2015). MIS = marine isotope stage.

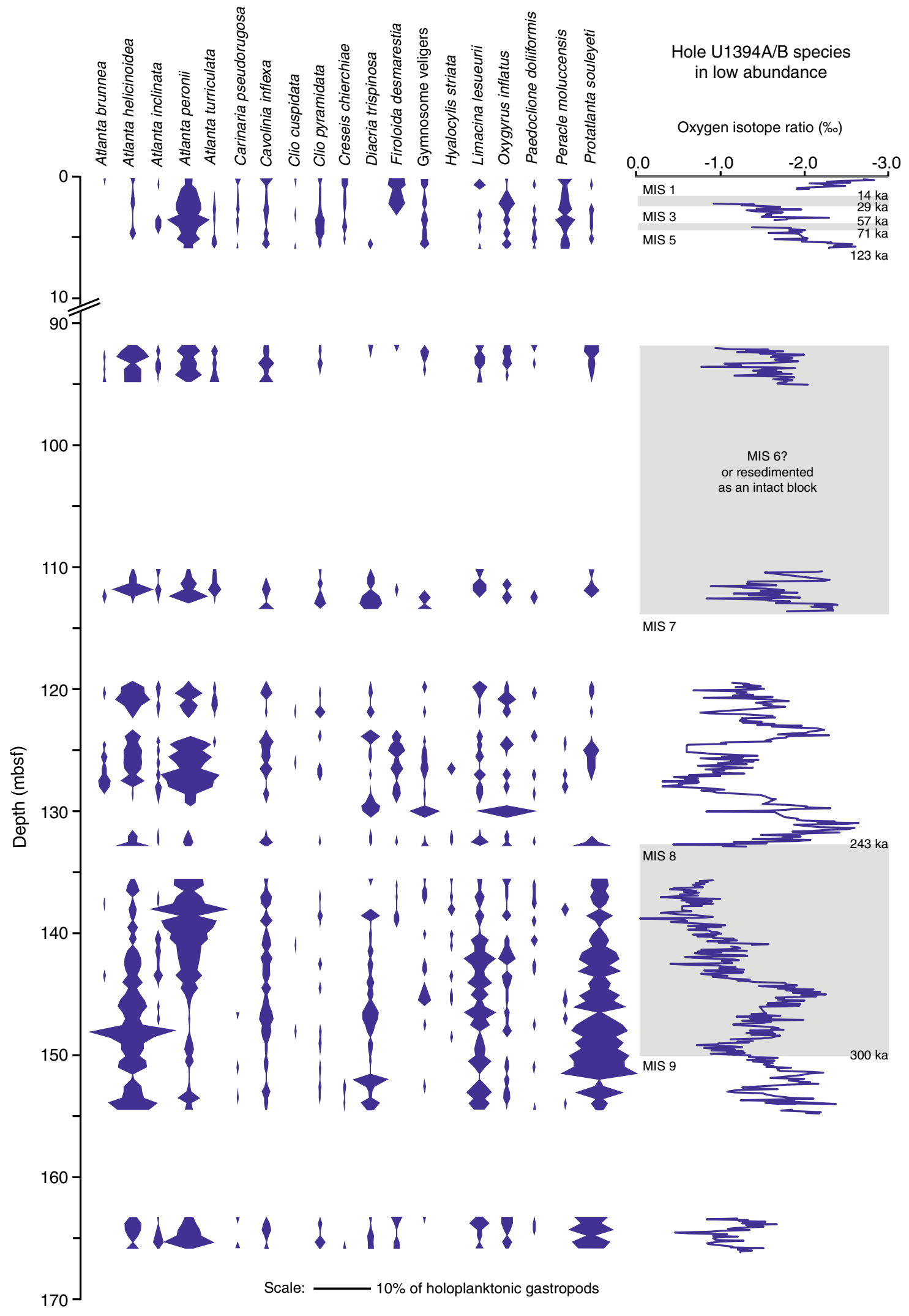


Figure F7. Common to rare species (generally abundance $<10 \%$ ) of holoplanktonic gastropods in the upper 30 $\mathrm{m}$ at Site U1395 with oxygen isotope stratigraphy (Coussens et al., 2015). MIS = marine isotope stage.

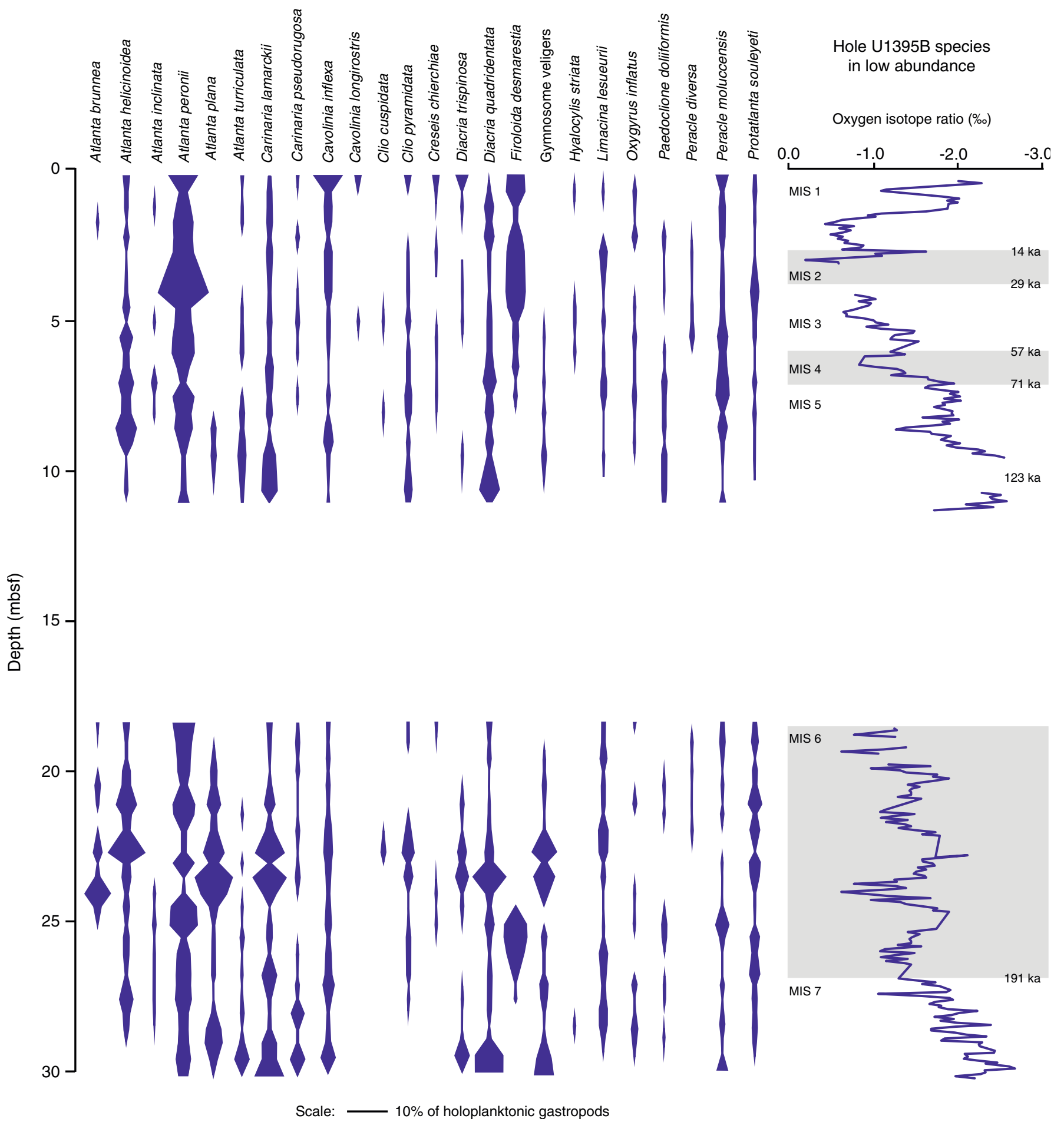


Figure F8. Common to rare species (generally abundance $<10 \%$ ) of holoplanktonic gastropods in the upper 6 $\mathrm{m}$ at Site CAR-MON 2 (Wall-Palmer et al., 2014b) with oxygen isotope stratigraphy (Le Friant et al., 2008). MIS $=$ marine isotope stage.

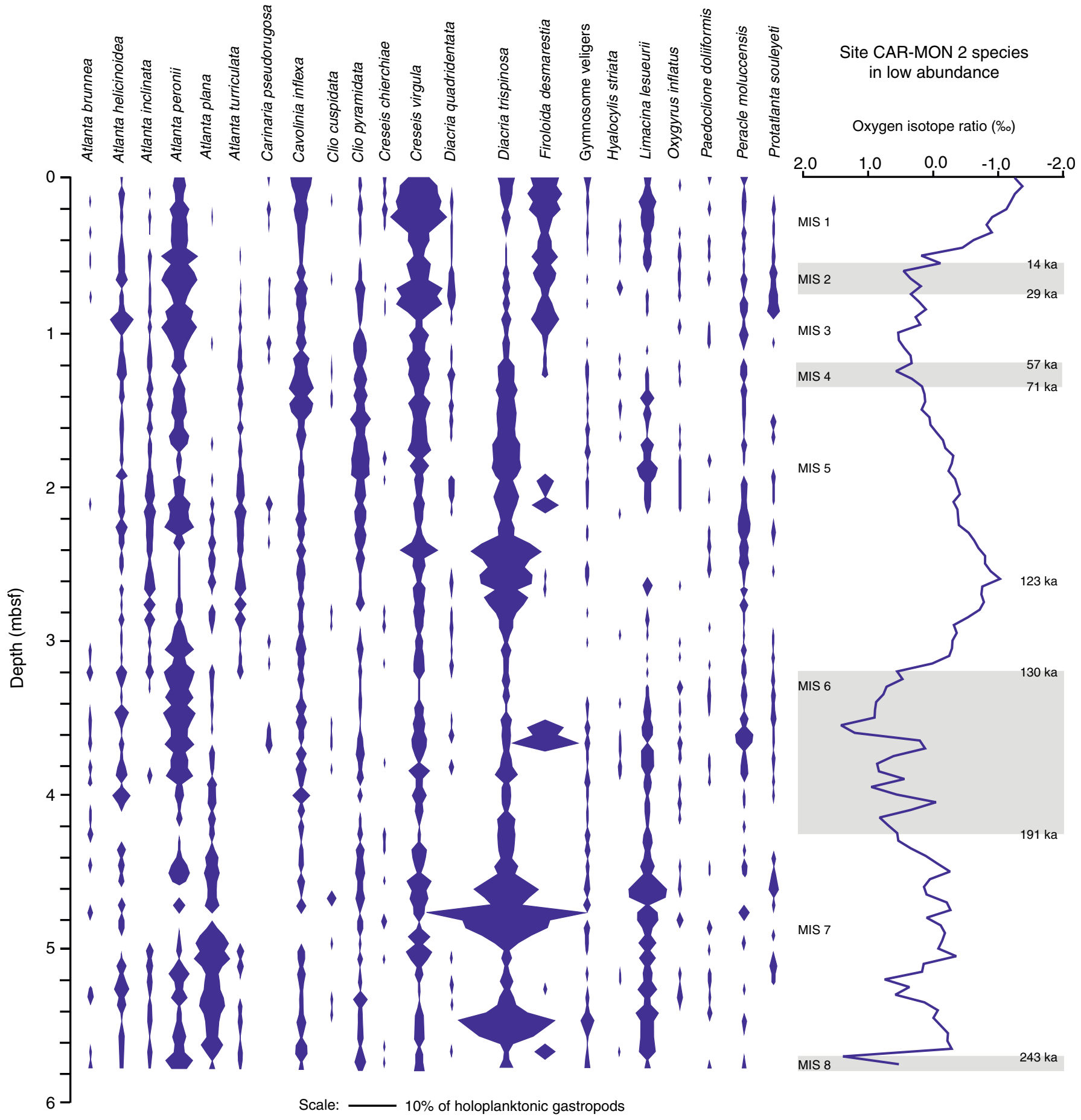


Table T1. Environmental preferences for dominant planktonic gastropod species.

\begin{tabular}{lcccl}
\hline \multicolumn{1}{c}{ Species } & $\begin{array}{c}\text { Temperature } \\
\text { range }\left({ }^{\circ} \mathrm{C}\right)\end{array}$ & Salinity range & $\begin{array}{c}\text { Depth range } \\
(\mathrm{m})\end{array}$ & Notes \\
\hline $\begin{array}{l}\text { Atlanta plana } \\
\text { Atlanta selvagensis }\end{array}$ & - & - & - & Warm-water cosmopolitan species \\
Carinaria lamarckii & - & - & - & Warm-water cosmopolitan species \\
Creseis clava & $10-27.9$ & $35.5-36.7$ & $50-750$ & Warm-water cosmopolitan species \\
Creseis virgula & $15-27.9$ & $35.0-36.7$ & $50-319$ & Warm-water cosmopolitan species \\
Diacria quadridentata & $19.0-25.5$ & $35.7-36.3$ & $0-700$ & Warm-water cosmopolitan species \\
Gleba cordata & - & - & - & \\
Heliconoides inflatus & $14-28$ & $35.5-36.7$ & $232-236$ & Warm-water cosmopolitan species \\
Limacina bulimoides & $13.8-27.8$ & $35.5-36.7$ & $80-120$ & Very abundant subtropical species \\
Limacina trochiformis & $13.8-27.9$ & $35.5-36.8$ & $50-165$ & Tropical species \\
Styliola subula & $14.2-27.7$ & $35.5-36.7$ & $81-234$ & Subtropical species \\
\hline
\end{tabular}

$-=$ unknown. 


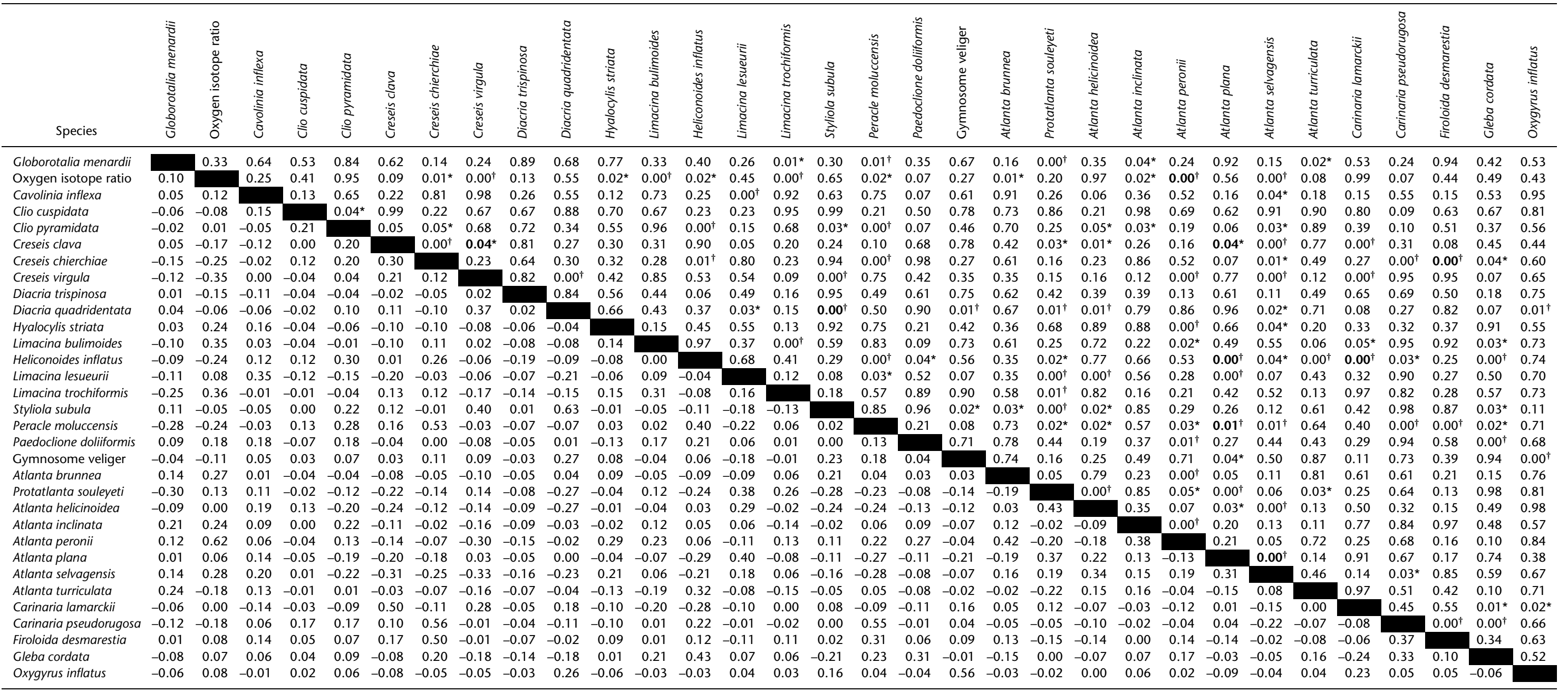

$*=$ correlations significant to $0.05, \dagger=$ correlations significant to 0.01 . Upper section represents $p$-values, lower section represents $r$-values. Bold $=$ correlations reproducible across all three sites 


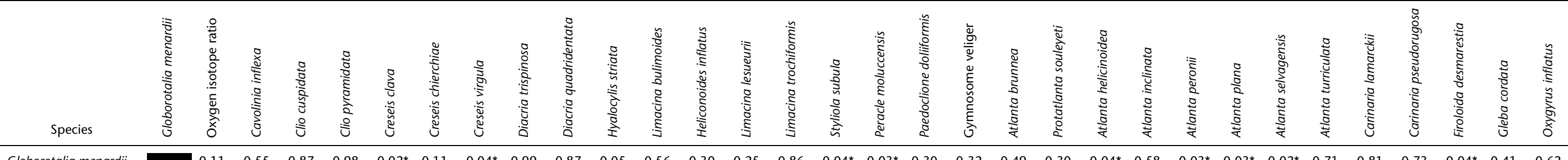

Globorotalia menardii Oxygen isotope ratio
Cavolinia inflexa

Clio cuspidata

Clio pyramidata

Creseis clava
Creseis chierchiae

Creseis virgula

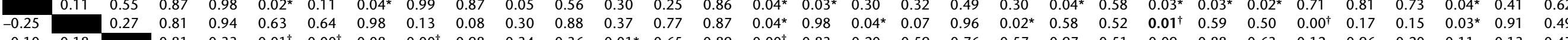

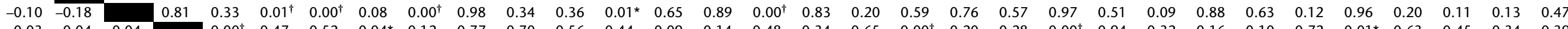

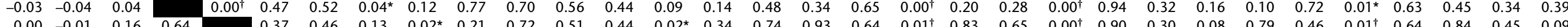

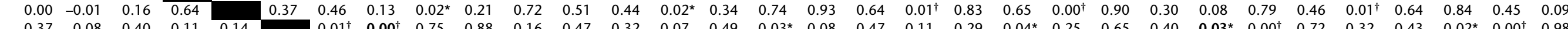

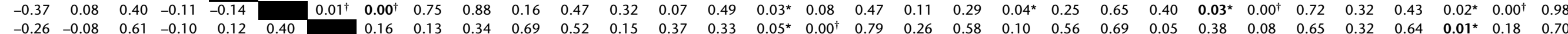

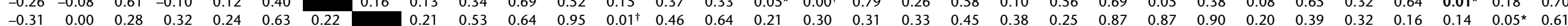

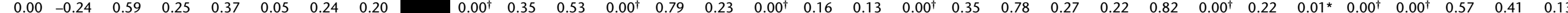

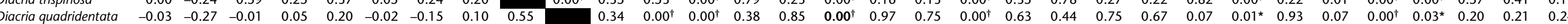

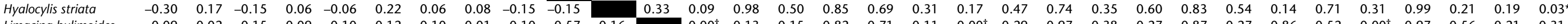

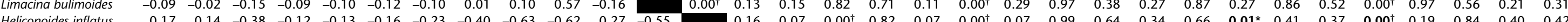

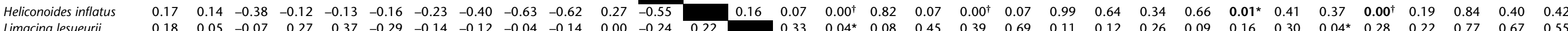

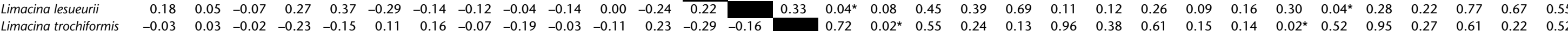

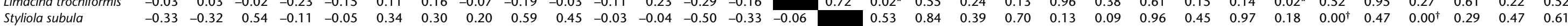

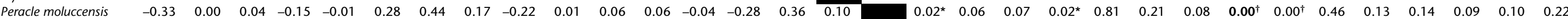

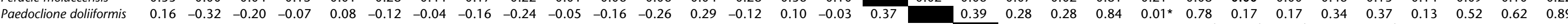

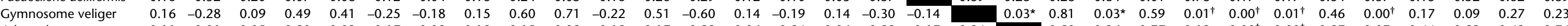
Atlanta brunnea Protatlanta souleyeti Atlanta helicinoidea Atlanta inclinata Atlanta plana

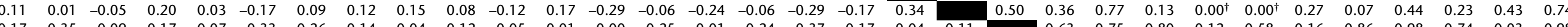

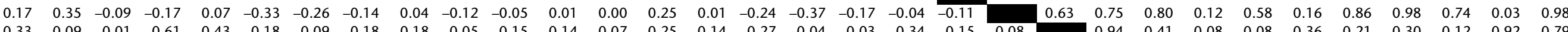

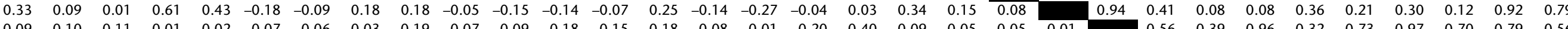

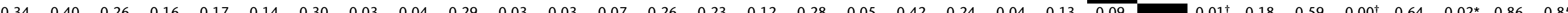
Atlanta plana selvagensis $\begin{array}{lllllllllllllllllllllllll}0.33 & -0.09 & -0.03 & 0.23 & 0.27 & -0.33 & -0.14 & 0.02 & 0.54 & 0.39 & -0.10 & 0.18 & -0.39 & 0.22 & -0.23 & 0.01 & -0.46 & -0.22 & 0.61 & 0.59 & 0.24 & 0.27 & -0.14 & -0.40 & 0.04\end{array}$

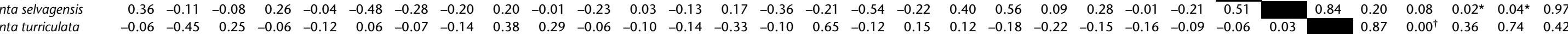
Carinaria lamarckii Carinaria pseudorugosa
Firoloida desmarestia
Gleba cordata \begin{tabular}{llllllllllllllllllllllllllllllllll}
0.04 & -0.22 & 0.01 & 0.39 & 0.41 & -0.16 & -0.16 & 0.16 & 0.50 & 0.72 & -0.16 & 0.52 & -0.58 & 0.17 & -0.01 & 0.11 & -0.24 & -0.15 & 0.89 & 0.29 & 0.03 & 0.20 & -0.06 & -0.44 & 0.63 & 0.20 & 0.03 & 0.03 & 0.65 & 0.15 & 0.08 & 0.52 \\
\hline
\end{tabular} Oxygrrus inflatus

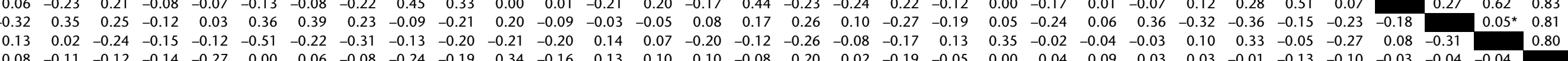

$*=$ correlations significant to $0.05, \dagger=$ correlations significant to 0.01 . Upper section represents $p$-values, lower section represents $r$-values. Bold $=$ correlations reproducible across all three sites 
Species

Globorotalia menardii Oxygen isotope ratio Clio cuspidata Clio pyramidata Creseis clava Creseis cherchia
Creseis virgula Creseis virgula Diacria quadridentata Hyalocylis striata Limacina bulimoides Heliconoides inflatus Limacina lesueuri styliola subula Styliola subula
Peracle moluccensis

Paedoclione doliiformis Gaedoclione doliliform
Gymnosome veliger Atlanta brunnea Protatlanta souleyeti Atlanta helicinoidea Atlanta peronii Atlanta plana

Atlanta selvagensis

Carinaria lamarckii Carinaria pseudorugosa Gleba cordata Oxygyrus inflatus

\section{-0.07
-0.38
-0.02
-0.13
-0.38
0.04}

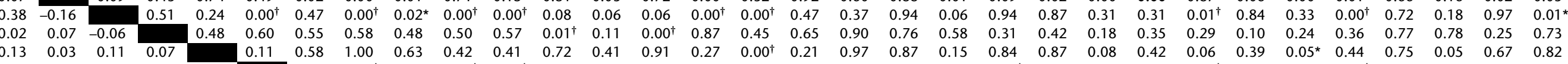

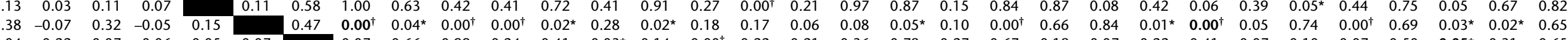

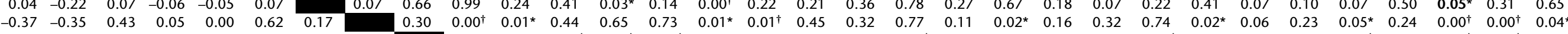

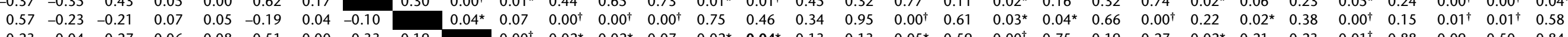

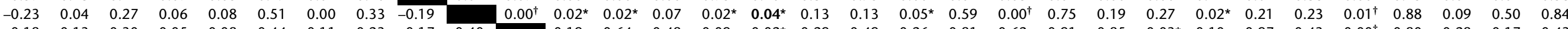
$\begin{array}{lllllllllllllllllllllllllllllllll}-0.18 & 0.13 & 0.30 & 0.05 & 0.08 & 0.44 & -0.11 & 0.23 & -0.17 & 0.40 & 0.19 & 0.64 & 0.48 & 0.09 & 0.02^{*} & 0.29 & 0.49 & 0.26 & 0.81 & 0.62 & 0.91 & 0.85 & 0.03^{*} & 0.10 & 0.97 & 0.43 & 0.00^{\dagger} & 0.80 & 0.28 & 0.17 & 0.43\end{array}$

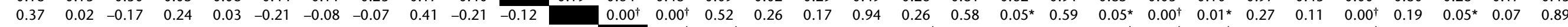

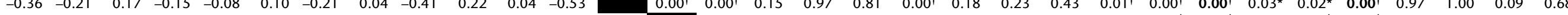

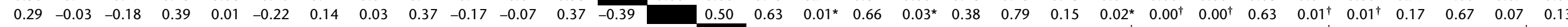

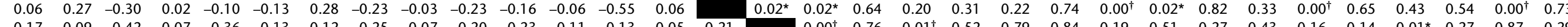

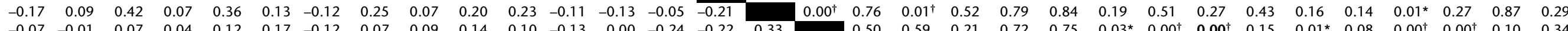

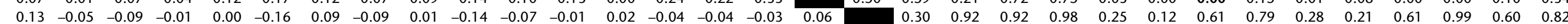

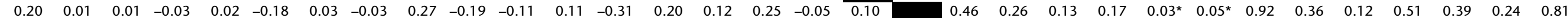
$\begin{array}{llllllllllllllllllllllllllllllll}0.14 & 0.25 & -0.18 & 0.05 & -0.13 & -0.15 & -0.10 & -0.15 & 0.05 & -0.05 & -0.02 & 0.05 & -0.13 & 0.08 & 0.10 & -0.06 & 0.12 & -0.01 & 0.07 & & 0.47 & 0.53 & 0.07 & 0.10 & 0.61 & 0.90 & 0.06 & 0.80 & 0.34 & 0.40 & 0.58 & 0.06\end{array}$

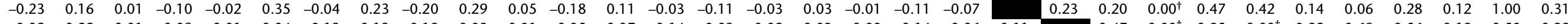

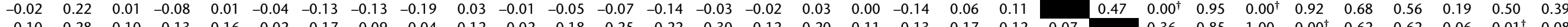

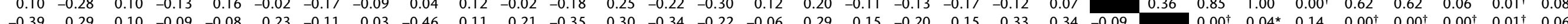

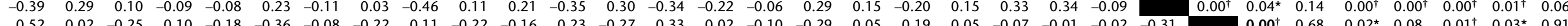

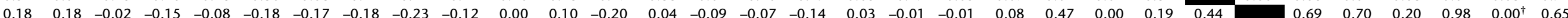

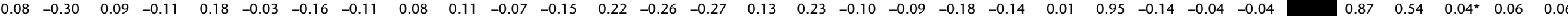

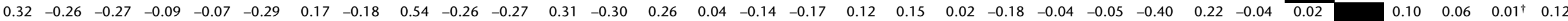

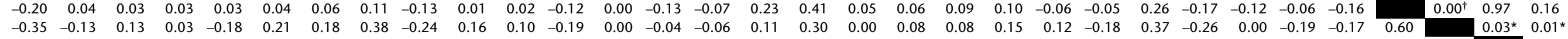

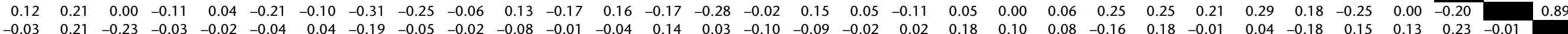

$*=$ correlations significant to $0.05, \dagger=$ correlations significant to 0.01 . Upper section represents $p$-values, lower section represents r-values. Bold $=$ correlations reproducible across all three sites 